УДК 159.922:928.23

DOI https://doi.org/10.32838/2709-3093/2021.3/20

Колінець Г.Г.

Міжнародний гуманітарно-педагогічний інститут «Бейт-Хана»

\title{
ПСИХОЛОГІЧНІ ОСОБЛИВОСТІ ВЗАСМОЗВ'ЯЗКУ СТРУКТУРНИХ КОМПОНЕНТІВ МАТЕМАТИЧНИХ ДОСЛІДНИЦЬКИХ ЗДІБНОСТЕЙ ШКОЛЯРІВ
}

У статті розглянуто проблему психологічних особливостей взаємозв 'язків між структурними компонентами математичних дослідницьких здібностей старшокласників. Вказано на іï актуальність.

Доведено, щя формування математичних дослідницьких здібностей, які є підструктурою загальної математичної наукової спрямованості особистості на науковий пошук, відкриття закономірностей, відповідають сучасним завданням перебудови системи освіти $i$ є основою для становлення особистості, готової творчо застосовувати набуті знання й досліднищькі здібності у подальшому житті.

Проаналізовано основні підходи до проблеми формування досліднищьких здібностей, розвитку їх структурних компонентів, до розв 'язання проблеми взаємозв'язку інтелекту і спеціальних здібностей у вітчизняній та зарубіжній психології.

Розкрито значення факторного аналізу, суть якого полягає у виділенні співпадаючих факторів під час корелячії результатів дослідження різноманітними тестами, що дає можливість визначити, які психологічні властивості беруть участь у виконанні певної діяльності. Завдяки иьому виявляються взаємозв'язки і співвідношення між показниками структурних компонентів здібностей.

Встановлено, що між усіма компонентами математичних дослідницьких здібностей у старшокласників на початку дослідження виявлено взаємозв'язки, характер яких вказує на існування нерівномірностей у їх розвитку. Більш однорідними виступають такі показники, як швидкість перебігу мисленнєвої діяльності, уміння сприймати формальну структуру задачі та інтелектуальний потенціал. В експериментальних класах після проведення спеціально організованого навчання міџнішими виявились взаємозв'язки між мотивацією досягнень та формалізованим сприйманням структури задач.

3'ясовано провідні фактори рівнів прояву показників математичних дослідницьких здібностей старшокласників: мотиваиія досягнень, швидкість перебігу мисленнєвої діяльності та загальні творчі здібності, щъо говорить про високий ступінь інтеграції між ними та відображає реальні психологічні передумови їх формування у складі математичної наукової творчості.

Ключові слова: наукова творчість, математичні дослідницькі здібності, творчі здібності, мотивачія досягнень, факторний аналіз.

Постановка проблеми. Важливим завданням перебудови системи освіти сьогодні є створення умов для розвитку обдарованості учнів, розкриття їх особистісного та творчого потенціалу. Лише фахівці з розвиненим на належному рівні творчим мисленням спроможні відповідати за своє професійне майбутне, проявляючи готовність правильно оцінити й використати передовий досвід, творчо переробивши його та збагативши власними самостійними доробками. Саме від освіти залежить вирішення важливої проблеми сучасного суспільства - формування активної, компетентної, творчої особистості на основі розвитку творчої діяльності, інтелектуальних та дослідницьких здібностей, у тому числі й математичних, які $є$ підструктурою загальної математичної наукової спрямованості особистості на науковий пошук, відкриття закономірностей, уміння знаходити нові, нестандартні способи розв'язання задач. Тому проблема розвитку структурних компонентів математичних дослідницьких здібностей старшокласників та встановлення зв'язку між ними $є$ актуальною.

Аналіз останніх досліджень і публікацій. $€$ різні підходи до проблеми формування дослідницьких здібностей, розвитку їх структурних компонентів.

Найбільш поширеною є теорія розвивального навчання (П.П. Блонський, Л.С. Виготський, 
П.Я. Гальперін, Г.С. Костюк), яка підкреслює значення розвитку структурних компонентів інтелекту у процесі навчання, засобів цілеспрямованого впливу на мислення учнів (Н.П. Абакелія, В.В. Маткін та інші). Такими засобами ряд дослідників (Г.О. Балл [1, с. 54], В.О. Моляко [2, с. 53], В.А. Крутецький [3, с. 247] та інші) вважають розв'язування учнями пізнавальних задач, організованих у спеціальну систему (особливо для розвитку творчого мислення).

Досліджуючи розвиток математичних здібностей у процесі розв'язування дослідницьких задач, М.П. Пихтар [4, с. 16] зазначив, що успішність у науково-дослідницькій математичній діяльності залежить від креативної спрямованості особистості, нестандартного способу мислення, високого рівня інтелекту і мотиваційно-вольової забезпеченості. Розкриваючи концептуальні засади формування і розвитку творчого мислення школяpiв, О.С. Чашечникова [5, с. 149] вказує на необхідність створення системи творчого середовища у процесі вивчення математики.

Принципово різними є підходи до розв'язання проблеми взаємозв'язку інтелекту і спеціальних здібностей у вітчизняній та зарубіжній психології. Якщо вітчизняні психологи намагались виявити структуру здібностей на основі якісного аналізу діяльності учнів, то в західноєвропейській і американській психології домінуючим $є$ кількісний підхід. Слід згадати, що ще на початку XX ст. був сформульований закон «універсальної єдності інтелектуальної функції» (Ч. Спірмен), який стверджував, що в основі виконання будь-якого інтелектуального тесту завжди лежать два фактори: загальний, або генеральний, для всіх тестів, як фундаментальна особливість розуму, і специфічний для кожного тесту. Ця модель отримала назву біфакторної моделі Спірмена (g - загальний фактор, S - специфічний фактор).

Ієрархічна теорія факторів (С. Берт, Ф. Вернон) визнає існування загального фактору (g) і ряду групових факторів. Аналіз інтелекту пов'язаний 3 виділенням двох групових головних факторів, які відповідають «вербальним» і «практичним» здібностям, які поділяються на другорядні групові та специфічні фактори (X. Олдхем, М. Баракат та інші).

Факторний аналіз особливо поширився в останні десятиліття. Суть його полягає у виділенні співпадаючих факторів під час кореляції результатів дослідження різноманітними тестами. Завдяки цьому виявляються взаємозв'язки і співвідношення між показниками різних тестів. На думку багатьох психологів-дослідників, це дає можливість визначити, які психологічні властивості і якості беруть участь у виконанні певної діяльності (Берт, Вернон, Томсон, Баракат). Так, зокрема, М. Баракат, вивчаючи структуру математичних здібностей, виділив і ідентифікував 6 факторів: g - загальний, V - вербальний, $\mathrm{S}$-просторовий, $\mathrm{N}$-обчислювальний, $\mathrm{M}$-пам'ять, і так званий математичний фактор [6, с. 22].

Вважаємо, що такий підхід до дослідження структури спеціальних здібностей поряд з позитивними сторонами має і ряд суттєвих недоліків: важко отримати об' єктивні результати, базуючись лише на кількісних результатах розв'язання тестів і не аналізуючи характер діяльності учнів при цьому, адже вони значною мірою залежатимуть як від характеру запропонованих тестів, так і від ступеня інформаційної підготовленості учнів. Це питання потребує досліджень. Залишаються нерозв'язаними й питання щодо психологічних особливостей взаємозв'язків між характеристиками компонентів структури дослідницьких здібностей старшокласників.

Постановка завдання. Мета статті - розкрити психологічні особливості взаємозв'язків між показниками структурних компонентів математичних дослідницьких здібностей старшокласників.

Виклад основного матеріалу. Дослідницькі математичні здібності є підструктурою загальної математичної наукової спрямованості особистості на науковий пошук, відкриття закономірностей, вміння знаходити нові, нестандартні спроби розв'язання задач.

Структурними психологічними компонентами математичних дослідницьких здібностей $є$ креативна спрямованість особистості, дивергентний спосіб мислення, досить високий рівень інтелекту та емоційно-вольова забезпеченість математикодослідницької діяльності індивіду.

3 метою вивчення взаємозв'язків між різними характеристиками інтелектуального i мотиваційно-особистісного компонентів у структурі математичних дослідницьких здібностей старшокласників, крім якісного аналізу одержаних матеріалів, ми використали кореляційний і факторний аналізи. 3 цією метою за формулою Пірсона [7, с. 283] було обчислено коефіцієнти кореляції та складено матриці інтеркореляційних зв'язків між показниками: швидкістю перебігу мисленнєвої діяльності, інтелектом, формалізованим сприйманням структури задач, загальними творчими здібностями, мотивацією досягнень. 
Кореляційний аналіз показав, що найтісніший зв'язок $(R=0,593)$ встановлюється між загальними творчими здібностями та інтелектом. Одержаний коефіцієнт кореляції вказує на таку тенденцію: вищому рівневі загальних творчих здібностей старшокласників відповідає вищий рівень розвитку інтелекту і навпаки. Це пояснюється однією з психологічних закономірностей математичних дослідницьких здібностей, яка полягає у взаємозв'язку інтелекту з репродуктивними або творчими математичними здібностями. Проте це спостерігається не у всіх старшокласників, отже, високий інтелект сам по собі не є достатньою умовою для розвитку дослідницьких здібностей, які $є$ одним 3 видів творчих здібностей. Таким чином, вищезгадані показники не є тотожними, попри існування єдності між ними.

Одержані результати свідчать, що загальні творчі здібності мають чітко виражений зв'язок 3 мотивацією досягнень $(R=0,584)$.

Досить чіткий зв'язок й між швидкістю перебігу мисленнєвої діяльності та формалізованим сприйманням структури задач $(R=0,571)$, що свідчить про те, що у старшокласників прогрес у здібностях розв'язувати математичні задачі дослідницького характеру поєднується із здібностями у сприйманні формальної структури задачі. Але це спостерігається у незначної кількості учнів, про що свідчить порівняння результативної сторони їх діяльності. Значний зв'язок наявний між швидкістю перебігу мисленнєвої діяльності й загальними творчими здібностями $(R=0,522)$, що пояснюється тим, що дослідницькі здібності є одним із видів творчих здібностей.

Кореляційний аналіз показав здебільшого високий ступінь взаємозв'язку між швидкістю перебігу мисленнєвої діяльності і мотивацією досягнень та інтелектом, коефіцієнти кореляції між якими становлять відповідно 0,456 та 0,452. Високий взаємозв'язок між інтелектом та формалізованим сприйманням $(\mathrm{R}=0,448)$. Досить високий коефіцієнт кореляції між загальними творчими здібностями та формалізованим сприйманням структури задач $(R=0,425)$, що вказує на здатність старшокласників з високими загальними творчими здібностями більш якісно сприймати формальну структуру задач, проявляючи при цьому оригінальність, самостійність думки, уміння встановлювати причинно-наслідкові зв'язки між даними умови задач.

Невисока кореляція між мотивацією досягнень та інтелектом $(\mathrm{R}=0,317)$ і формалізованим сприйманням структури задач $(\mathrm{R}=0,320)$, що свідчить, на нашу думку, про відсутність або низький рівень розвитку оволодіння мисленнєвими операціями в частини старшокласників. Отже, між усіма компонентами математичних дослідницьких здібностей у старшокласників на початку дослідження виявлено взаємозв'язки, характер яких вказує на існування нерівномірностей у розвитку цих компонентів. Більш однорідними за наявністю однакових тенденцій виступають такі показники, як швидкість перебігу мисленнєвої діяльності, уміння сприймати формальну структуру задачі та інтелектуальний потенціал. Бачимо, що у старшокласників на початку дослідження інтелектуальний компонент чіткіше виражений, ніж мотиваційноособистісний.

Порівняння результатів виконання другої серії завдань, проведених у контрольній та експериментальній групах старшокласників, свідчить про ефективність спеціального навчання, яке проводилось для школярів експериментальної групи. Показники сформованості вибраних структурних компонентів математичних дослідницьких здібностей було оброблено методами кореляційного аналізу, і одержані значення подано в таблицях 1,2 .

Таблиця 1

Таблиця інтеркореляцій між показниками математичних дослідницьких здібностей старшокласників (II-й зріз) у контрольній групі

\begin{tabular}{|c|c|c|c|c|c|}
\hline & $Z_{1}$ & $Z_{2}$ & $Z_{3}$ & $Z_{4}$ & $Z_{5}$ \\
\hline$Z_{1}$ & - & 0,563 & 0,720 & 0,445 & 0,463 \\
\hline$Z_{2}$ & 0,563 & - & 0,605 & 0,497 & 0,507 \\
\hline$Z_{3}$ & 0,720 & 0,605 & - & 0,635 & 0,382 \\
\hline$Z_{4}$ & 0,445 & 0,497 & 0,635 & - & 0,402 \\
\hline$Z_{5}$ & 0,463 & 0,507 & 0,382 & 0,402 & - \\
\hline
\end{tabular}

Таблиця 2

Таблиця інтеркореляцій між показниками математичних дослідницьких здібностей старшокласників

(II-й зріз) у експериментальній групі

\begin{tabular}{|c|c|c|c|c|c|}
\hline & $Z_{1}$ & $Z_{2}$ & $Z_{3}$ & $Z_{4}$ & $Z_{5}$ \\
\hline$Z_{1}$ & - & 0,776 & 0,741 & 0,400 & 0,458 \\
\hline$Z_{2}$ & 0,776 & - & 0,549 & 0,414 & 0,485 \\
\hline$Z_{3}$ & 0,741 & 0,549 & - & 0,615 & 0,389 \\
\hline$Z_{4}$ & 0,400 & 0,414 & 0,615 & - & 0,388 \\
\hline$Z_{5}$ & 0,458 & 0,485 & 0,389 & 0,388 & - \\
\hline
\end{tabular}

Умовні позначення: $Z_{1}$ - швидкість перебігу мисленнєвої діяльності; $Z_{2}$ - загальні творчі здібності; $Z_{3}$ - мотивація досягнень; $Z_{4}$ - інтелект; $Z_{5}$ - формалізоване сприймання структури задачі 
Порівняння відповідних коефіцієнтів кореляції, одержаних у I-й та II-й серіях експерименту для контрольних класів, показує зміни взаємозв'язків між окремими параметрами, які відбулись в умовах шкільного навчання.

Отже, враховуючи величину стандартної помилки коефіцієнтів кореляції, можна констатувати, що за період навчання між I-м і II-м зрізами у значної частини учнів контрольної групи залишаються постійними взаємозв'язки: швидкості перебігу мисленнєвої діяльності з мотивацією досягнень; мотивації досягнень 3 формалізованим сприйманням структури задач. Це свідчить про рівномірність у темпах становлення вказаних структурних компонентів.

Зменшуються зв'язки між швидкістю перебігу мисленнєвої діяльності та формалізованим сприйманням структури задач, загальними творчими здібностями та інтелектом. 3 огляду на якісний аналіз матеріалів дослідження, вважаємо, що деяке зниження вищевказаних зв'язків пов'язано 3 труднощами в оволодінні старшокласниками більш складного навчального матеріалу (спад успішності).

Помітно зміцнюються взаємозв'язки між швидкістю перебігу мисленнєвої діяльності та мотивацією досягнень, загальними творчими здібностями та формалізованим сприйманням структури задач, мотивацією досягнень та інтелектом. Отже, у старшокласників загалом підвищується роль мотиваційно-особистісного та інтелектуального компонентів.

Розглянемо результати впливу спеціально організованого навчання у старшокласників експериментальної групи на міцність зв'язків між показниками дослідницьких здібностей. В експериментальній групі, на відміну від контрольної, знижується кореляція загальних творчих здібностей і мотивації досягнень, швидкості перебігу мисленнєвої діяльності та формалізованого сприймання структури задач. Дещо слабшими стають взаємозв'язки між загальними творчими здібностями та інтелектом, інтелектом та сприйманням формальної структури задач. Інтенсивніше зміцнюється кореляція мотивації досягнень та інтелекту. Посилюються взаємозв'язки між загальними творчими здібностями та формалізованим сприйманням структури задач, між мотивацією досягнень та формалізованим сприйманням структури задач.

Матеріали другого зрізу показують існування найбільшої кореляції між швидкістю перебігу мисленнєвої діяльності та загальними творчими здібностями $(\mathrm{R}=0,776)$ та між швидкістю перебігу мисленнєвої діяльності й мотивацією досягнень $(\mathrm{R}=0,741)$, що говорить про високий ступінь інтеграції між ними. Порівняння одержаних зв'язків з відповідними значеннями у контрольних класах виявило значний позитивний вплив цілеспрямованої роботи з формування математичних дослідницьких здібностей старшокласників.

Насамперед помітно зросла кількість учнів, які приступають до розв'язання задач, усвідомивши їх умови та встановивши аналітико-синтетичні зв'язки між даними. Загалом це стосувалось розв'язання алгебраїчних завдань на доведення та мисленнєвих задач. Зросла кількість старшокласників 3 такою важливою індивідуальною особливістю процесу мислення, як гнучкість, що сприяло результативнішому розв'язанню задач 3 недостатніми, достатніми та зайвими даними.

У ході занять у школярів значно вдосконалився рівень аналітико-синтетичної діяльності, що полегшило перехід від конкретного до абстрактного і навпаки; підвищились рівні гнучкості, оригінальності мислення. Спеціально спрямована робота допомагала виробленню таких прийомів, які формували самостійність думки та індивідуальний стиль у розв'язанні задач. При цьому запропоновані принципи розв'язання математичних задач, вдосконалюючись, ставали у школярів інструментом розвитку математичних дослідницьких здібностей.

Таким чином, загальна тенденція зміцнення взаємозв'язків упродовж періоду навчання старшокласників між I та II зрізами у контрольній групі виявляється найбільшою мірою між швидкістю перебігу мисленнєвої діяльності та мотивацією досягнень, загальними творчими здібностями та сприйманням формалізованої структури задач, мотивацією досягнень та інтелектом. В експериментальних класах така тенденція спостерігається між швидкістю перебігу мисленнєвої діяльності та загальними творчими здібностями і мотивацією досягнень, між мотивацією потреби в досягненнях та сприйманням формалізованої структури задач. Це свідчить про більшу ефективність експериментального навчання для успішного формування математичних дослідницьких здібностей у старшокласників.

Проведений факторний аналіз матриць інтеркореляцій дозволив виділити провідні фактори рівнів прояву показників математичних дослідницьких здібностей старшокласників: перший фактор - мотивація досягнень, другий фактор - швидкість перебігу мисленнєвої діяльності 
та загальні творчі здібності, що підтверджує існування єдності та взаємозв'язку між ними.

Висновки. Проведений аналіз взаємозв'язків між виділеними показниками математичних дослідницьких здібностей старшокласників показав тісний зв'язок між загальними творчими здібностями та швидкістю перебігу мисленнєвої діяльності, між мотивацією досягнень та швидкістю перебігу мисленнєвої діяльності, що говорить про високий ступінь інтеграції між ними та відображає реальні психологічні передумови ï формування у складі математичної наукової творчості. Матеріали нашого дослідження не вичерпують усіх питань, що стосуються вивчення взаємозв'язку структурних компонентів математичних дослідницьких здібностей старшокласників. Подальше дослідження цієї проблеми повинно бути спрямовано на виявлення способу та характеру їх взаємозв'язку в цілісній структурі дослідницької діяльності школярів.

\section{Список літератури:}

1. Балл Г.А. Теория учебных задач: Психолого-педагогический аспект. Москва, Педагогика. 1990. 184 с.

2. Моляко В.А. Психология решения школьниками творческих задач. Київ, Рад. школа. 1983. 96 с.

3. Крутецкий В.А. Психология математических способностей школьников. Москва, Институт Практической Психологии. 1998. 416 с.

4. Пихтар М.П. Розвиток математичних здібностей школярів у діяльності Малої академії наук : автореф. дис. ...пед. Наук : 13.00.02. Нац. пед. ун-т ім. М.П. Драгоманова. К. 2011.20 с.

5. Чашечнкова О.С. Концептуальні засади формування і розвитку творчого мислення школярів в ході навчання математики. Педагогічні науки: теорія, історія, інновачійні технології: науковий журнал. Суми. СумДПУ імені А.С.Макаренка. 2013. №2 (28). С. 141-152.

6. Колінець Г.Г. Психологічні передумови формування математичних дослідницьких здібностей у старшокласників. дис. канд. психол. наук: 19.00.07 / Інститут психології ім. Г.С.Костюка АПН України. Київ, 1999. 172 с.

7. Руденко В.М., Руденко Н.М. Математичні методи в психології. Київ, Академвидав. 2009. 384 с.

\section{Kolinets H.H. PSYCHOLOGICAL FEATURES OF THE RELATIONSHIP BETWEEN STRUCTURAL COMPONENTS OF MATHEMATICAL RESEARCH ABILITIES OF SCHOOLCHILDREN}

The article considers the problem of psychological features of the relationships between the structural components of mathematical research abilities of high school students. Its relevance is indicated.

It is proved that the formation of mathematical research abilities, which are the substructure of the general mathematical scientific orientation of the individual to scientific research, discovery of patterns, meet modern challenges of restructuring the education system and is the basis for becoming a person ready to creatively apply acquired knowledge and research abilities in later life.

The main approaches to the problem of formation of research abilities, development of their structural components, to the solution of the problem of interrelation of intelligence and special abilities in domestic and foreign psychology are analyzed.

The importance of factor analysis is revealed, the essence of which is to highlight the coincident factors in the correlation of research results with various tests, which makes it possible to determine which psychological properties are involved in performing certain activities. This reveals the relationships and relationships between the indicators of the structural components of abilities.

It was found that between all components of mathematical research abilities in high school students at the beginning of the study revealed relationships, the nature of which indicates the existence of irregularities in their development. Indicators such as the speed of mental activity, the ability to perceive the formal structure of the problem and intellectual potential are more homogeneous. In experimental classes, after conducting specially organized training, the relationship between the motivation of achievements and the formalized perception of the structure of tasks became stronger.

The leading factors of levels of manifestation of indicators of mathematical research abilities of high school students are found out: motivation of achievements, speed of mental activity and general creative abilities, which speaks of a high degree of integration between them and reflects real psychological preconditions of their formation as a part of mathematical scientific creativity.

Key words: scientific creativity, mathematical research abilities, creative abilities, motivation of achievements, factor analysis. 